medRxiv preprint doi: https://doi.org/10.1101/2020.08.31.20185488; this version posted September 2, 2020. The copyright holder for this preprint (which was not certified by peer review) is the author/funder, who has granted medRxiv a license to display the preprint in

All rights reserved. No reuse allowed without permission.

\title{
SARS-CoV-2 Viral RNA Load Dynamics in the Nasopharynx of Infected Children
}

2 Kai-qian $\underline{K a m}^{1-3}$ (MBBS), Koh Cheng $\underline{\text { Thoon }}^{1-4}$ (MBBS), Matthias Maiwald ${ }^{2,5,6}$ (MD), Chia Yin

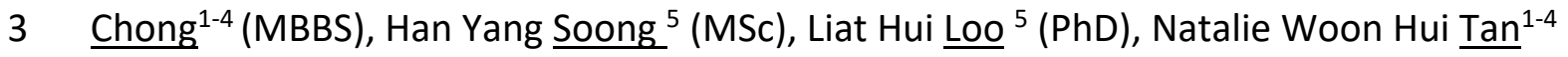

4 (MBBS), Jiahui $\underline{\mathrm{Li}}^{1-3}$ (MBBS), Karen Donceras $\underline{\text { Nadua }}^{1-3}(\mathrm{MD})$, Chee Fu Yung ${ }^{1,2,4}$

5

$6{ }^{1}$ Infectious Disease Service, Department of Pediatrics, KK Women's and Children's Hospital,

7 Singapore

$8 \quad{ }^{2}$ Duke-NUS Medical School, Singapore

$9 \quad{ }^{3}$ Yong Loo Lin School of Medicine, National University of Singapore, Singapore

$10{ }^{4}$ Lee Kong Chian School of Medicine, Imperial College London, Nanyang Technological

11 University, Singapore

12 5epartment of Pathology and Laboratory Medicine, KK Women's and Children's Hospital,

13 Singapore

$14{ }^{6}$ Department of Microbiology and Immunology, National University of Singapore, Singapore

15

16 Keywords: SARS-CoV-2, viral load, COVID-19, children, cycle threshold 
medRxiv preprint doi: https://doi.org/10.1101/2020.08.31.20185488; this version posted September 2, 2020. The copyright holder for this preprint (which was not certified by peer review) is the author/funder, who has granted medRxiv a license to display the preprint in

All rights reserved. No reuse allowed without permission.

\section{Summary}

20 It is important to understand the temporal trend of pediatric severe acute respiratory

21 syndrome coronavirus 2 (SARS-CoV-2) viral load to estimate the transmission potential of

22 children in schools and communities. We determined differences in SARS-CoV-2 viral load

23 dynamics between nasopharyngeal samples of infected asymptomatic and symptomatic

24 children. The daily cycle threshold values of SARS-CoV-2 in the nasopharynx of a cohort of

25 infected children were collected for analysis. Among 17 infected children, 10 (58.8\%) were

26 symptomatic. Symptomatic children, when compared to asymptomatic children, had higher

27 viral load (mean cycle threshold on day 7 of illness 28.6 versus $36.7, p=0.02$ ). Peak SARS-

28 CoV-2 viral loads occured around days 2-3 of illness/days of diagnosis in infected children.

29 After adjusting for the estimated date of infection, the higher SARS-CoV-2 viral loads in

30 symptomatic children remained. We postulate that symptomatic SARS-CoV-2-infected

31 children may have higher transmissibility than asymptomatic children. As peak viral load in

32 infected children occurred in the early stage of illness, viral shedding and transmission in the

33 pre-symptomatic phase probable. Our study highlights the importance of screening for

34 SARS-CoV-2 in children with epidemiological risk factors, even when they are asymptomatic

35 in order to improve containment of the virus in the community, including educational

36 settings.

$\underline{\text { Key points }}$

- Symptomatic children had higher SARS-CoV-2 viral loads in the nasopharynx than asymptomatic children, which may indicate that symptomatic children have higher transmissibility. 
medRxiv preprint doi: https://doi.org/10.1101/2020.08.31.20185488; this version posted September 2, 2020. The copyright holder for this preprint (which was not certified by peer review) is the author/funder, who has granted medRxiv a license to display the preprint in All rights reserved. No reuse allowed without permission.

- Peak SARS-CoV-2 viral loads occurred early around 2-3 days post symptom onset iin children and therefore, pre-symptomatic transmission of the virus is probable.

- Symptom based screening for SARS-CoV-2 may not be effective in diagnosing coronavirus disease 2019 (COVID-19) in children as a proportion of children may be asymptomatic or pauci-symptomatic. may be carriers of the virus and contribute to transmission. 
medRxiv preprint doi: https://doi.org/10.1101/2020.08.31.20185488; this version posted September 2, 2020. The copyright holder for this preprint (which was not certified by peer review) is the author/funder, who has granted medRxiv a license to display the preprint in

All rights reserved. No reuse allowed without permission.

56 The viral load of the novel coronavirus, severe acute respiratory syndrome coronavirus 2

57 (SARS-CoV-2), has been reported to peak within the first week of disease in throat and

58 sputum samples in the adult population [1-2]. The viral loads in a small group of asymptomatic infected adults were also shown to be similar to those of symptomatic infected adults, implying a transmission potential of asymptomatic patients [2]. A proportion of COVID-19-infected children are known to asymptomatic or have mild to moderate disease [3-5]. Previously, we reported a paucisymptomatic SARS-CoV-2-infected infant who presented with high viral load prior to symptom onset, viral shedding up to day 18 of illness and significant environmental viral contamination [6, 7]. A recent study in Korea also suggests that SARS-CoV-2 can be detected in children for a mean of more than 2 weeks and a proportion of the infected children are asymptomatic despite high viral load [8]. There is a need to improve the understanding of the viral load dynamics of SARS-CoV-2 in infected children so as to postulate the role of children in the transmission of COVID-19 in schools and the community. In this study, we analyzed the daily trends of SARS-CoV-2 viral load from nasopharyngeal samples of infected symptomatic and asymptomatic pediatric patients.

KK Women's and Children's Hospital (KKH) is an 830-bed hospital that provides care for approximately 500 children's emergency daily attendances and 12,000 deliveries per year. It is the primary hospital for evaluation and isolation of COVID-19 in the pediatric population in Singapore. A line list of confirmed pediatric cases who presented to our institution from 23 March 2020 to 5 April 2020 was extracted from hospital records. Confirmed cases that were diagnosed by positive SARS-CoV-2 PCR from nasopharyngeal swabs using the real-time reverse transcription polymerase chain reaction ( $r R T-P C R)$ for the E gene were included. 
medRxiv preprint doi: https://doi.org/10.1101/2020.08.31.20185488; this version posted September 2, 2020. The copyright holder for this preprint (which was not certified by peer review) is the author/funder, who has granted medRxiv a license to display the preprint in

All rights reserved. No reuse allowed without permission.

80 Nasopharyngeal swabs were taken daily from the confirmed cases. A cycle threshold (Ct) of

8145 is considered to be undetectable for the virus. Age, gender and the Ct values of all nasopharyngeal swabs for SARS-CoV-2 for each child were also obtained. Most of these children were contacts of confirmed cases in their household. In our institution, children were considered to have recovered from COVID-19 and discharged from the hospital when they had negative SARS-CoV-2 PCR results from 2 nasopharyngeal swabs on consecutive days.

The Ct values were reported in relation to the day of illness or day of diagnosis for symptomatic and asymptomatic patients, respectively (Figure $1 \mathrm{~A})$. As an additional analysis to mitigate bias in timing of detection between symptomatic and asymptomatic cases, we incorporated an estimated day of infection in Figure 1B. The children were most likely to have been infected by their household confirmed cases_during this early period of the pandemic in Singapore with detailed contact tracing and testing. Therefore, we used the date of symptom onset for index household COVID-19 case as the estimated day of infection for this additional analysis. If this information was missing, we used the average duration calculated from patients with the information available. flocked swabs and $1 \mathrm{~mL}$ of universal transport medium. From this medium, $200 \mu \mathrm{L}$ was used for extraction of viral nucleic acids using the EZ1 Virus Mini Kit v2.0 (Qiagen, Hilden,

101 Germany) into $60 \mu \mathrm{L}$ of eluate. rRT-PCR targeting the SARS-CoV-2 E gene was performed according to the method by Corman et al [9]. All reactions were run on a QuantStudio 5 
medRxiv preprint doi: https://doi.org/10.1101/2020.08.31.20185488; this version posted September 2, 2020. The copyright holder for this preprint (which was not certified by peer review) is the author/funder, who has granted medRxiv a license to display the preprint in

All rights reserved. No reuse allowed without permission.

104

105

106

107

108

109

110

111

112

113 Continuous variables were normal in distribution; they were expressed as mean (range) and

used in PCRs, and with conversion factors, this represented 1/60th of the swab contents per reaction. The positive control consisted of a plasmid with a SARS-CoV-2 E gene insert, adjusted to 1000 copies per reaction. During the study period, the mean Ct value of all positive control PCRs was 29.86 and the standard deviation was \pm 0.68 . Thus, with the conversion factor, a Ct value of 29.86 corresponded to approximately $6 \times 10^{4}$ virus genome copies per swab. All first-time positive results for each individual patient were confirmed by a second PCR assay, the Fortitude PCR kit (A*Star, Singapore) on a CFX96 thermocycler (BioRad, Hercules, CA, USA). compared with 2 samples T test. Categorical variables were expressed as numbers (\%). A two-sided $\alpha$ of less than 0.05 was considered statistically significant. Statistical analyses were done using the SPSS software, version 23 (IBM, Armonk, NY, USA). The average Ct values for each day of illness and diagnosis were obtained for the asymptomatic and symptomatic children. The graphs were drawn to compare the average $\mathrm{Ct}$ trends on each day of illness/diagnosis between the two groups. The study was approved by the institutional ethics review board. Written informed consent was waived in light of the need to inform public health outbreak control policies.

123 From 23 March to 5 April 2020, 17 children with confirmed COVID-19 via rRT-PCR E gene 124 assay were cared for as inpatients at our institution. The median age of the cohort was 7.7 125 years old (range: 0.3 to 15.8 years old). In our cohort, 10 (58.8\%) of the children were 126 symptomatic. All symptomatic children had a mild illness with upper respiratory tract 127 infection and their symptoms resolved by day 5 of illness. No complications or evidence of 
medRxiv preprint doi: https://doi.org/10.1101/2020.08.31.20185488; this version posted September 2, 2020. The copyright holder for this preprint (which was not certified by peer review) is the author/funder, who has granted medRxiv a license to display the preprint in

All rights reserved. No reuse allowed without permission.

128 pneumonia were observed. All asymptomatic children remained well with no development

129 of symptoms until discharge.

130

131 The mean duration of viral shedding was about 16 days (range: 3-29 days) in our cohort.

132 Symptomatic children had longer durations of viral shedding but this was not statistically

133 significant (mean 17 days versus 14 days, $p=0.48$ ). Higher viral loads were observed in

134 symptomatic children when compared to asymptomatic children (mean cycle threshold on

135 day 7 of illness 28.6 versus $36.7,95 \% \mathrm{Cl}=1.9$ to $14.3, \mathrm{p}=0.02$ ). Peak SARS-CoV-2 viral loads

136 occured around days 2-3 of illness in symptomatic children or days of diagnosis in

137 asymptomatic children, respectively (Figure 1A). After adjusting for the estimated date of

138 infection, SARS-CoV-2 viral loads remained higher in symptomatic children when compared

139 to asymptomatic children, but the durations of viral shedding between the two groups were

140 similar (Figure 1B).

141

142 We present the daily nasopharyngeal SARS-CoV-2 Ct values of the asymptomatic and

143 symptomatic infected children in our cohort. The mean duration of viral shedding was 16

144 days and the longest duration of viral shedding was 30 days in a previously symptomatic

145 child. The detection of early viral peaks at days 2-3 of illness in our pediatric cases concurs

146 with data from limited paediatric studies $[10,11]$. This raises the possibility that children

147 with COVID-19 may transmit the virus to others during the early stage of the illness.

148 Although we were unable to establish if the virus was already detectable in high viral loads

149 in the pre-symptomatic phase in our cohort of patients, the high viral load in our

150 symptomatic children in the very early stage of illness implies the transmission potential of 
medRxiv preprint doi: https://doi.org/10.1101/2020.08.31.20185488; this version posted September 2, 2020. The copyright holder for this preprint (which was not certified by peer review) is the author/funder, who has granted medRxiv a license to display the preprint in

All rights reserved. No reuse allowed without permission.

151 pre-symptomatic children if they are not identified and isolated in the pre-symptomatic

152 phase.

153

154 Contrary to reports of COVID-19-infected adults showing similar viral load trends in

155 asymptomatic and symptomatic infected individuals [2], our findings revealed that

156 symptomatic COVID-19-infected children may have higher viral loads in the initial stage of

157 illness than asymptomatic children. Mi et al recently reported similar findings from a

158 smaller cohort in South Korea but daily swab data was not available [11]. Importantly, even

159 after we accounted for the estimated day of infection for both symptomatic and

160 asymptomatic children, the viral loads continued to be higher in symptomatic children. This

161 suggests that symptomatic children may have a higher risk of transmitting the virus than

162 asymptomatic children. This finding and our daily viral load data could be used to guide

163 modelling work to help undertand the role of children in driving transmisison in schools and

164 the wider population, in order to inform public health interventions including future

165 vaccination policies.

166

167 We found that the majority of patients had detectable virus even on day 7 of

168 illness/diagnosis and the mean duration of viral shedding was 16 days. If testing resources

169 need to be preserved, we suggest that infected children do not need to be tested for the

170 virus for at least the first 7 days of illness/diagnosis to confirm they no longer need to be

171 isolated unless clinically indicated. Isolation of pediatric COVID-19 cases to prevent ongoing

172 transmission may need to continue for at least 2 to 3 weeks. Children with epidemiological

173 links to confirmed cases in the household and schools should be placed under quanratine 
medRxiv preprint doi: https://doi.org/10.1101/2020.08.31.20185488; this version posted September 2, 2020. The copyright holder for this preprint (which was not certified by peer review) is the author/funder, who has granted medRxiv a license to display the preprint in

All rights reserved. No reuse allowed without permission.

174 for a least 2 weeks, as these children may shed the virus during the asymptomatic or pre-

175 symptomatic phase.

176

177 Although our sample size is limited, daily nasopharyngeal specimens were taken for every

178 case which accounted for individual level variations in viral shedding patterns in infected

179 children. The findings from our cohort may not be representative of other pediatric

180 populations but our cohort included multi-ethnic patients (Chinese, Malay, Indian, Eurasian

181 ethnicities). Our PCR assay was not set up to be exactly quantitative, but approximate viral

182 loads can be gleaned from Ct values, using the dilution factors and the fact that positive

183 controls contained 1000 copies of a plasmid per reaction. As per all observational studies, it

184 is difficult to ascertain the exact day of acquisition for the infected children. For our

185 secondary analysis (Figure 1B), we assumed that the children were infected on the onset

186 date of the index household COVID-19 case. Epidemiological data from Singapore's

187 systematic contact tracing, testing and isolation policy supported this assumption during the

188 early phase of the pandemic [12].

190 In conclusion, our study found that symptomatic infected children have higher viral RNA

191 loads than asymptomatic children. We also detected peak viral load occurred very early in

192 children within about 2 to 3 days of infection which would suggest probable potential for

193 transmission before symptom onset. These findings highlights the importance of screening

194 for SARS-CoV-2 in children with epidemiological risk factors, even when they are

195 asymptomatic in order to improve containment of the virus in the community including

196 educational settings. 
medRxiv preprint doi: https://doi.org/10.1101/2020.08.31.20185488; this version posted September 2, 2020. The copyright holder for this preprint (which was not certified by peer review) is the author/funder, who has granted medRxiv a license to display the preprint in All rights reserved. No reuse allowed without permission.

\section{Acknowledgement}

199 The authors would like to thank all the staff of the Microbiology Section, Department of

200 Pathology and Laboratory Medicine, KK Women's and Children's Hospital for their

201 dedication and commitment in the challenging working conditions in this COVID-19

202 pandemic.

203

204 Competing interests

205 The authors declare no competing interests.

206

207 Funding/support

208 Nil

209 
medRxiv preprint doi: https://doi.org/10.1101/2020.08.31.20185488; this version posted September 2, 2020. The copyright holder for this preprint (which was not certified by peer review) is the author/funder, who has granted medRxiv a license to display the preprint in All rights reserved. No reuse allowed without permission.

\section{References}

211

212

1. Pan Y, et al. Viral load of SARS-CoV-2 in clinical samples. Lancet Infect Dis 2020;20(4):411-

412.

214

215

2. Zou L, et al. SARS-CoV-2 viral load in upper respiratory specimens of infected patients. $N$

EnglJ Med 2020;382(12):1177-1179.

217

218

3. Cai J, et al. A case series of children with 2019 novel coronavirus infection: clinical and

epidemiological features. Clin Infect Dis. Published online: 28 February 2020.

220 doi:10.1093/cid/ciaa198.

221

4. Qiu H, et al. Clinical and epidemiological features of 36 children with coronavirus disease

2019 (COVID-19) in Zhejiang, China: an observational cohort study. Lancet Infect Dis

2020;20(6):689-696.

225

226

5. Dong Y, et al. Epidemiology of COVID-19 among children in China. Pediatrics

2020;145(6):e20200702.

228

229 6. Kam KQ, et al. A well infant with coronavirus disease 2019 with high viral load. Clin Infect Dis 2020;71(15):847-849.

233 the isolation room of an infant with infection. Ann Intern Med 2020;173(3):240-242. 
medRxiv preprint doi: https://doi.org/10.1101/2020.08.31.20185488; this version posted September 2, 2020. The copyright holder for this preprint (which was not certified by peer review) is the author/funder, who has granted medRxiv a license to display the preprint in All rights reserved. No reuse allowed without permission.

234 8. Han MS, et al. Clinical characteristics and viral RNA detection in children with coronavirus

235 disease 2019 in the Republic of Korea. JAMA Pediatr. Published online: 28 August 2020.

236 doi:10.1001/jamapediatrics.2020.3988.

237

238

9. Corman VM, et al. Detection of 2019 novel coronavirus (2019-nCoV) by real-time RT-PCR.

239 Euro Surveill 2020;25(3):2000045.

240

241 10. Yonker LM, et al. Pediatric SARS-CoV-2: clinical presentation, infectivity, and immune

242 responses. J Pediatr. Published online: 18 August 2020. doi:10.1016/j.jpeds.2020.08.037.

243

244 11. Han MS, et al. Viral RNA Load in mildly symptomatic and asymptomatic children with

245 COVID-19, Seoul. Emerg Infect Dis. Published online: 4 June 2020.

246 doi:10.3201/eid2610.202449.

247

248 12. Pung R, et al. Investigation of three clusters of COVID-19 in Singapore: implications for

249 surveillance and response measures. Lancet 2020;395(10229):1039-1046.

250

251

252 
medRxiv preprint doi: https://doi.org/10.1101/2020.08.31.20185488; this version posted September 2, 2020. The copyright holder for this preprint (which was not certified by peer review) is the author/funder, who has granted medRxiv a license to display the preprint in perpetuity.

All rights reserved. No reuse allowed without permission.

Figure 1: SARS-CoV-2 temporal viral load dynamics in the nasopharynx of pediatric COVID-

\section{9 patients}

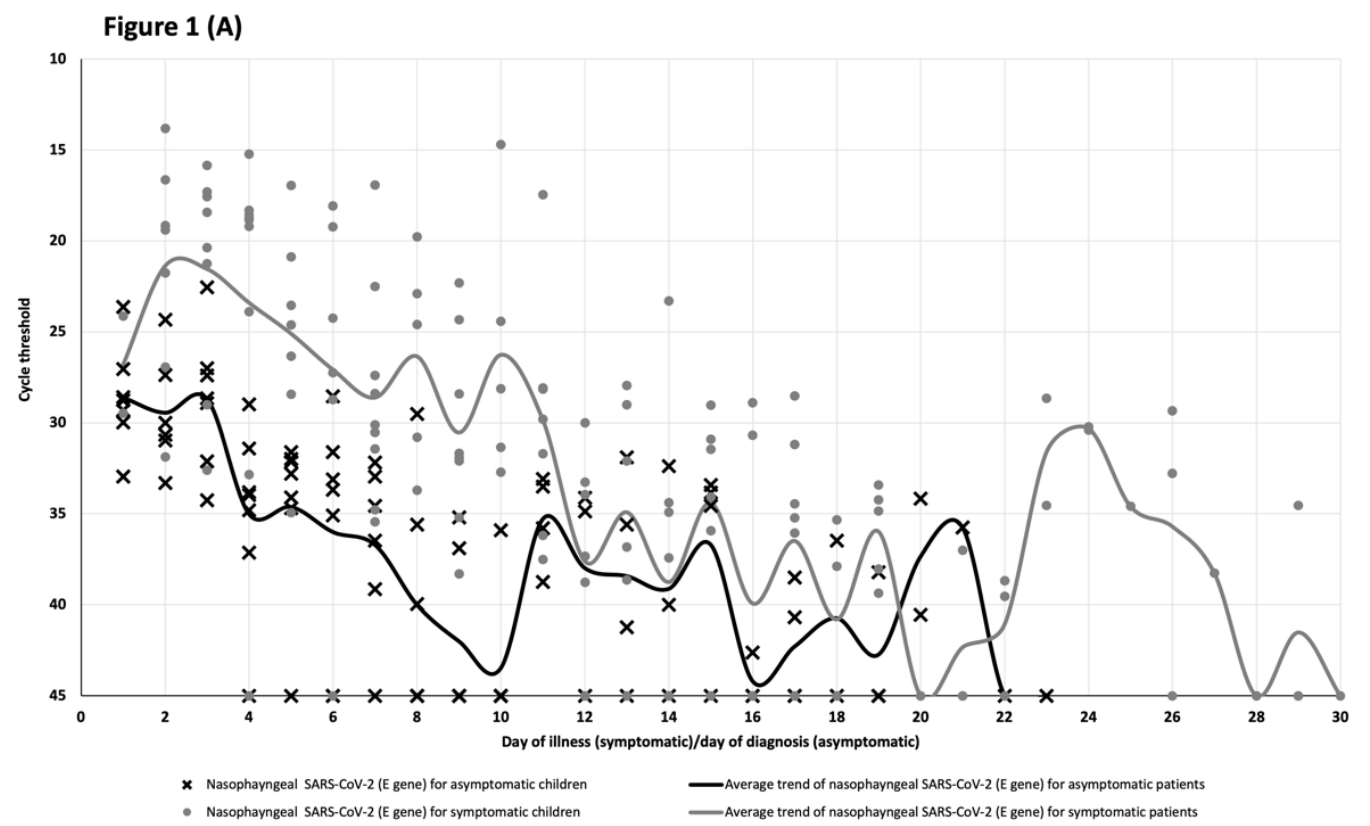

Figure 1 (B)

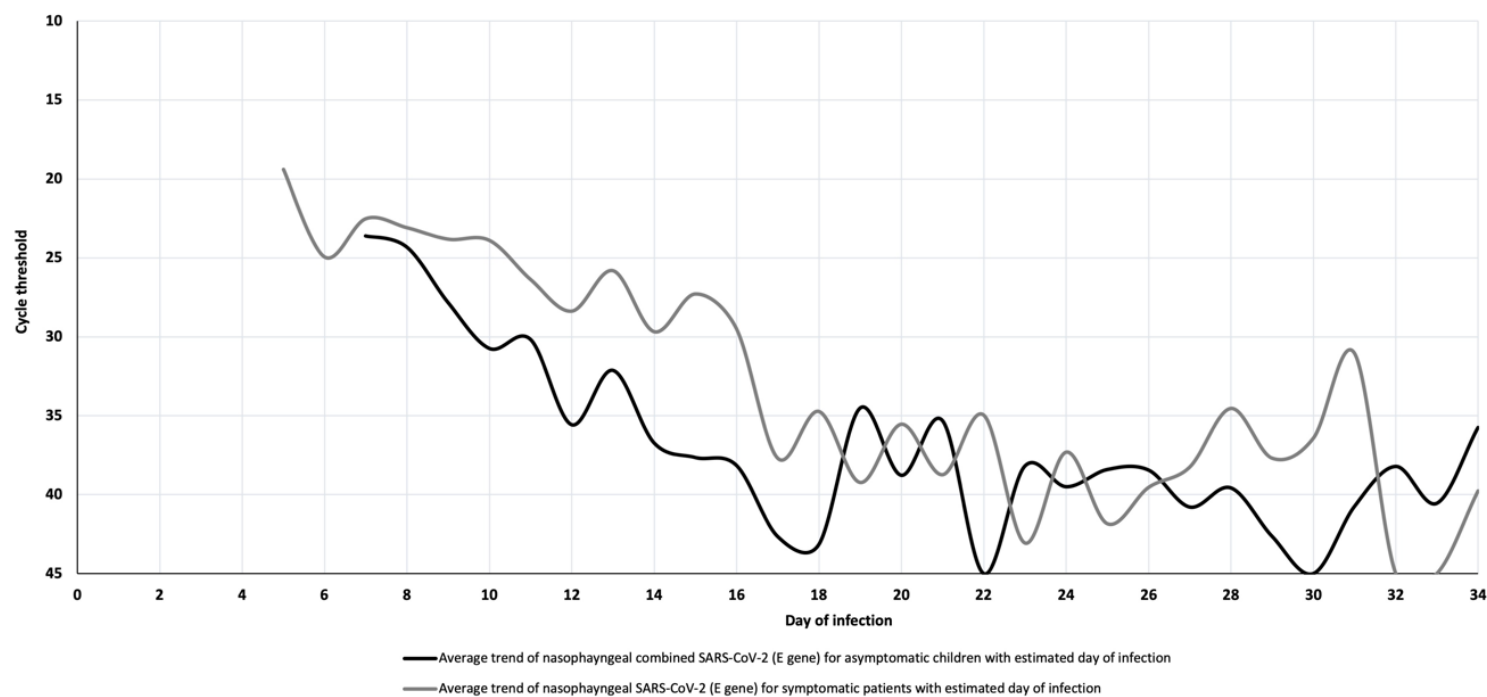

255 (A) Plotted against day of illness (symptomatic children) or day of diagnosis (asymptomatic

256 children).

257 (B) Plotted against estimated day of infection. 